\title{
Morphometrics and Growth Patterns of Halfbeak Fish (Nomorhamphus sp.) in Moramo River, South Konawe Regency
}

\author{
Sjamsu Alam Lawelle ${ }^{1 *}$, Asriyana ${ }^{1}$, and Andy Budi Nofrianto ${ }^{1}$ \\ ${ }^{1}$ Halu Oleo University, Faculty of Fisheries and Marine Sciences, Indonesia
}

\begin{abstract}
Halfbeaks (Nomorhamphus sp.) are freshwater fishes that inhabit the Moramo River. Data and scientific information of this species are still limited. This study aims to determine the morphometric characters and growth patterns of halfbeak fish in the Moramo River. This research was conducted from April to June 2020. The fish was caught using a modified seine net. The length of the net is $15 \mathrm{~m}$, width $1.2 \mathrm{~m}$, and mesh size $0.5 \times 0.5$ inches. There is a pocket in the middle of the net with $40 \mathrm{~cm}$ of diameter and $1.5 \mathrm{~m}$ of length. The fish were separated by sex, weighed, and preserved using $4 \%$ formalin. Measurement of 22 morphometric characters using calipers with an accuracy of $0.1 \mathrm{~mm}$. A total of 120 fish were caught, with 60 males and 60 females. Male fish have body lengths and weights ranging from 40.5-71 $\mathrm{mm}$ and $0.45-2.93 \mathrm{~g}$, while female fish have body lengths and weights ranging from $43.5-91.5 \mathrm{~mm}$ and $0.5-5.74 \mathrm{~g}$. The results of the growth patterns of male and female halfbeaks are negative allometric $(b<3)$.
\end{abstract}

\section{Introduction}

Halfbeak fish is one of the freshwater fishes from Zenarchopteridae families with limited distribution in the Indo-West Pacific region $[18,26]$. Halfbeak fish are divided into 2 types based on their habitat. First, halfbeak fish inhabit freshwater and brackish water ecosystems, including the genus of Dermogenys, Hemirhamphodon, Nomorhamphus, Tondanichthys, and Zenarchopterus. Second, halfbeak fish inhabit marine ecosystems, including Arrhamphus, Chriodorus, Euleptorhamphus, Hemiramphus, Hyporhamphus, Melapedalion, Oxyporhamphus, Reporhamphus, and Rhynchorhamphus [7,26]. Halfbeak fish are characterized by their upper jaws being shorter than their lower jaws [14,18]. Some species of halfbeak fish have unique and varied body colours.

Sulawesi is one of the islands in Indonesia that distributed several species of Nomorhamphus. Genus of Nomorhamphus is endemic to Sulawesi with 12 species including $N$. brembachi, $N$. liemi [10], $N$. celebensis [25], $N$. ebrardtii, $N$. hageni [8], $N$. kolonodalensis [2], N. lanceolatus, N. sagittarius [17], N. megarrhamphus [20], N. rex [16], N. towoetii [32], and N. weberi [11]. In Sulawesi, halfbeak fish can be found in rivers,

\footnotetext{
* Corresponding author: alawelle@yahoo.com
} 
swamps, lakes, and estuaries [7, 9, 16]. 3 ancient lakes are the habitat of halfbeak fish, namely Lake Poso in Central Sulawesi, Lake Matano, and Lake Towuti in South Sulawesi. At least there are more than one species of halfbeak fish that inhabits the lake [27].

Moramo River is one of the rivers in Southeast Sulawesi, which halfbeak fish inhabited. However, the specific species of Nomorhamphus in this river has not been clearly identified. There are no references or research data regarding this fish in the Moramo River. Several studies have been conducted on halfbeak fish in various locations other than the Moramo River are morphology [3, 16, 17], fish distribution [18, 23, 24], and food habits [33]. This study aims to determine morphometric characters and analyze the growth pattern to provide data and references regarding the halfbeak fish in the Moramo River. The benefit from this study is as basic information in further research to identify exact species of halfbeak fish in Moramo River.

\section{Materials and Methods}

\subsection{Research site}

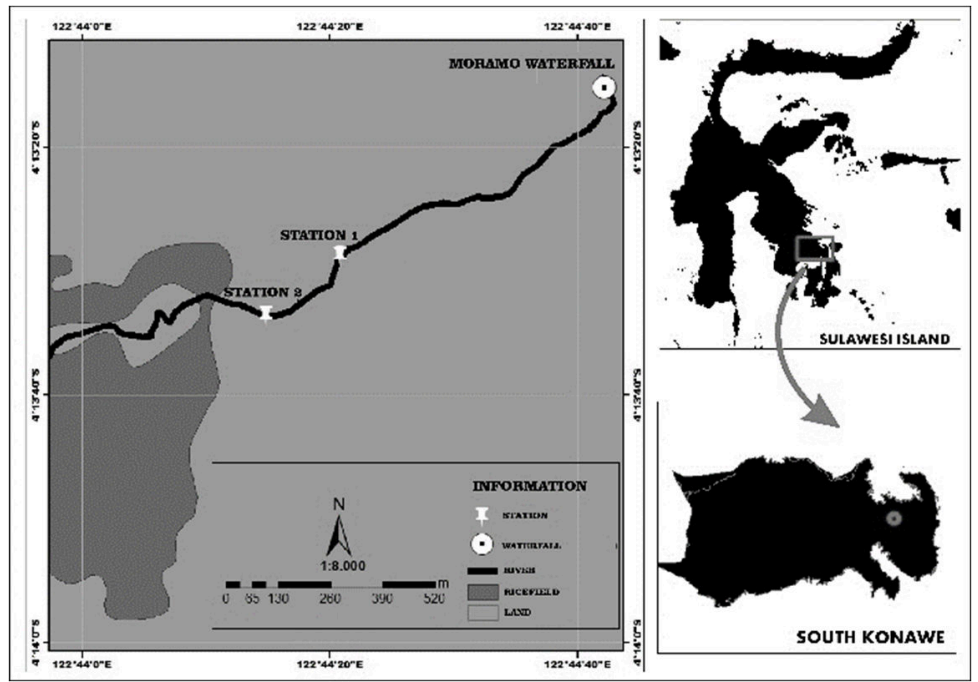

Fig.1. Maps of Moramo River, South Konawe

This study was conducted for three months, from April to June 2020 in Moramo River, Moramo District, Southeast Sulawesi Province (Fig 1). The sampling locations were determined using the purposive sampling technique. Station 1 is located at the coordinates of $4^{\circ} 13^{\prime} 33.61^{\prime \prime S}$ and $122^{\circ} 44^{\prime} 14.84^{\prime \prime} \mathrm{E}$ dominated by sand and small gravel. On the banks of the river, there are aquatic plants and rattan trees. Station 2 is located at the coordinates of $4^{\circ} 13 ' 28.84^{\prime \prime S}$ and $122^{\circ} 44^{\prime} 20.84^{\prime \prime E}$, dominated by muddy sand. On the banks of the river, there are rocks and grass.

\subsection{Fish collection}

This study uses a survey method, and the location is determined by purposive sampling. Fish were caught using a modified seine net (Fig 2) with capture intervals once every month. The net length is 15 meters, width 1.2 meters, and mesh size $0.5 \times 0.5$ inches. There 
is a pocket in the middle of the net with 40 centimeters of diameter and 1.5 meters of length. The fish were separated into two different buckets according to sex. The fish was anesthetized using ice. After fainting, the fish were weighed and preserved with $4 \%$ formalin.

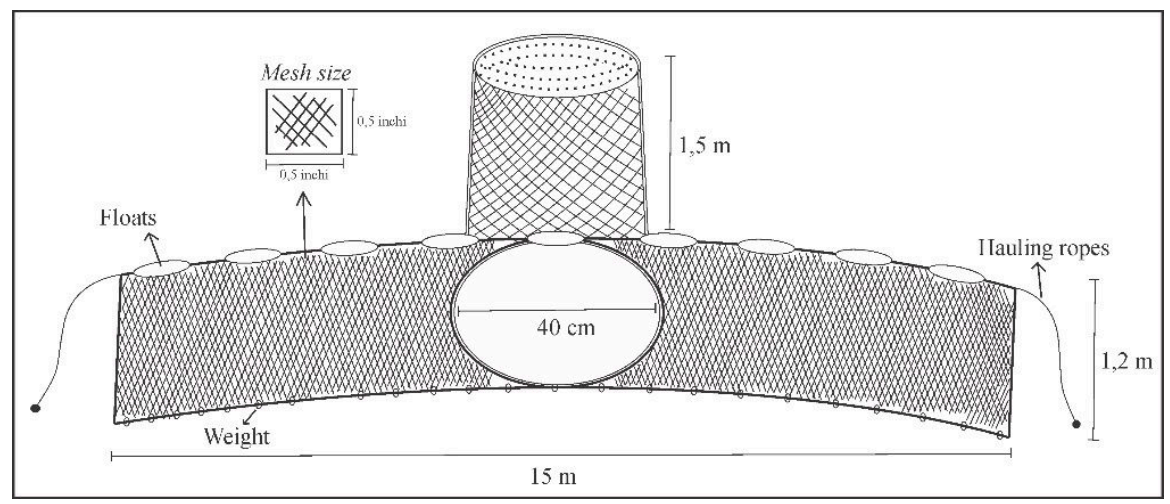

Fig. 2. Design of modified seine net

\subsection{Data analysis}

\subsubsection{Morphometric}

The morphometric measurement methods used in this study are common and truss morphometric. Measurement of morphometric characters using a caliper with an accuracy of $0.1 \mathrm{~mm}$. The number of morphometric characters measured in halfbeak fish is 22 characters [17]. The characters measured in millimeter include Total Length (TL); Standard Length (SL); Bony Orbital Diameter (ORBL); Head Length (HDL); Lower Jaw Length (LJL); Lower Jaw Length Brembach (LJLB) [21]; Upper Jaw Length (UJL); Snout to Pectoral-Fin Distance (SN-P $\left.\mathrm{P}_{1}\right)$; Body Depth at Pectoral-Fin Base $\left(\mathrm{BDP}_{1} \mathrm{~B}\right)$; Length of Pectoral-Fin $\left(\mathrm{LP}_{1} \mathrm{~F}\right)$; Length of Pectoral-Fin Base $\left(\mathrm{LP}_{1} \mathrm{~B}\right)$; Snout to Pelvic-Fin Distance $\left(\mathrm{SN}-\mathrm{P}_{2} \mathrm{~F}\right)$; Body Depth at Pelvic-Fin Base $\left(\mathrm{BDP}_{2} \mathrm{~B}\right)$; Length of Pelvic-Fin $\left(\mathrm{LP}_{2} \mathrm{~F}\right)$; Length of Pelvic-Fin Base $\left(\mathrm{LP}_{2} \mathrm{~B}\right)$; Pelvic-Fin to Caudal-Fin Distance $\left(\mathrm{P}_{2} \mathrm{~F}-\mathrm{CF}\right)$; Depth of Caudal Peduncle (DCP); Length of Caudal-Fin (LCF); Length of Anal-Fin (LAF); Length of AnalFin Base (LAB); Length of Dorsal-Fin (LDF); Length of Dorsal-Fin Base (LDB).

\subsubsection{Growth pattern}

The growth model is assumed from the analysis of the length-weight parameters. This means that in a section, it can be considered as a function of its length. The length-weight relationship information can be used to evaluate the fish condition and growth patterns, whether isometric or allometric [5, 6, 12, 22, 31]. The growth pattern equation has been calculated by the equation [1]:

$$
W=a L^{b}
$$

With; $W$ is the fish weight $(\mathrm{g}) ; L$ is the total length $(\mathrm{mm}) ; a$ is regression intercept (the point at which relationship curve of length-weight intersects the $y$-axis), and $b$ is regression coefficient (length-weight growth pattern estimator). The value of $b$ shows a growth pattern with the following categories: 
$\mathrm{b}=3 \quad$ : isometric (total length gain increase equal the weight gain)

$\mathrm{b}<3$ : allometric negative (total length gain increase exceeds weight gain)

$\mathrm{b}>3$ : positive allometric (weight gain exceeds total length gain)

The statistical $t$-test was used to determine whether the value of $b=3$ was correct or not. If $b \neq 3$, the fish has an allometric growth pattern. Whereas if $b=3$, the fish has an isometric growth pattern. In the length-weight relationship analysis, Microsoft Excel v.13 was used.

\section{Results}

\subsection{Morphometric measurement}

The total fish caught during the study was 120 halfbeak fish consists of 60 males and 60 females. Based on the measurement of morphometric of halfbeak fish in Moramo River (Table 1), it shows that there are size differences in some morphometric characters of male and female fish. Female halfbeak fish have morphometric characters sizes ranging from 0.5 $-91.5 \mathrm{~mm}$, and male halfbeak fish have a size of $0.5-71 \mathrm{~mm}$.

Table 1. Measurements of morphometric in millimeters

\begin{tabular}{|c|c|c|c|c|c|c|c|}
\hline \multirow{2}{*}{ No } & \multirow{2}{*}{ Morphometric Characters } & \multicolumn{3}{|c|}{ Female (in mm) } & \multicolumn{3}{|c|}{ Male (in mm) } \\
\hline & & Min & Max & Mean & Min & Max & Mean \\
\hline 1 & Standard Length (SL) & 36 & 79 & 57.11 & 34.5 & 63 & 45.75 \\
\hline 2 & Total Length (TL) & 43.5 & 91.5 & 66.94 & 40.5 & 71 & 53.99 \\
\hline 3 & $\begin{array}{l}\text { Lower Jaw Length Brembach } \\
\text { (LJLB) }\end{array}$ & 2 & 5.5 & 3.33 & 2 & 4.5 & 3.13 \\
\hline 4 & Lower Jaw Length (LJL) & 5.5 & 15 & 9.81 & 6 & 12 & 8.38 \\
\hline 5 & Upper Jaw Length (UJL) & 3.5 & 9.5 & 6.47 & 3.5 & 9 & 5.25 \\
\hline 6 & Bony Orbital Diameter (ORBL) & 3 & 4.5 & 3.57 & 2.5 & 4 & 3.25 \\
\hline 7 & Head Length (HDL) & 10 & 22 & 16.13 & 10 & 17 & 13.49 \\
\hline 8 & $\begin{array}{l}\text { Snout to Pectoral-Fin Distance } \\
\left(\mathrm{SN}-\mathrm{P}_{1} \mathrm{~F}\right)\end{array}$ & 11 & 23.5 & 17.34 & 11 & 18.5 & 14.48 \\
\hline 9 & $\begin{array}{l}\text { Snout to Pelvic-Fin Distance (SN- } \\
\left.\mathrm{P}_{2} \mathrm{~F}\right)\end{array}$ & 20 & 43.5 & 31.75 & 19 & 35 & 25.02 \\
\hline 10 & $\begin{array}{l}\text { Body Depth at Pectoral-Fin Base } \\
\text { (BDP } 1 \text { B) }\end{array}$ & 6 & 13 & 8.88 & 5.5 & 10 & 7.41 \\
\hline 11 & $\begin{array}{l}\text { Body Depth at Pelvic-Fin Base } \\
\left(\mathrm{BDP}_{2} \mathrm{~B}\right)\end{array}$ & 5 & 11.5 & 8.23 & 5 & 9 & 6.95 \\
\hline 12 & Depth of Caudal Peduncle (DCP) & 2.5 & 6.5 & 4.30 & 2.5 & 4.5 & 3.38 \\
\hline 13 & $\begin{array}{l}\text { Pelvic-Fin to Caudal-Fin Distance } \\
\left(\mathrm{P}_{2} \mathrm{~F}-\mathrm{CF}\right)\end{array}$ & 13.5 & 33 & 22.18 & 13 & 25 & 17.66 \\
\hline 14 & Length of Pectoral-Fin $\left(\mathrm{LP}_{1} \mathrm{~F}\right)$ & 5.5 & 12 & 8.54 & 5 & 10 & 7.50 \\
\hline 15 & $\begin{array}{l}\text { Length of Pectoral-Fin Base } \\
\left(\mathrm{LP}_{1} \mathrm{~B}\right)\end{array}$ & 0.5 & 3 & 1.22 & 0.5 & 2.5 & 0.98 \\
\hline 16 & Length of Dorsal-Fin (LDF) & 6 & 12 & 9.04 & 6 & 10 & 7.58 \\
\hline 17 & Length of Dorsal-Fin Base (LDB) & 4 & 9.5 & 7.18 & 3 & 8.5 & 5.23 \\
\hline 18 & Length of Pelvic-Fin $\left(\mathrm{LP}_{2} \mathrm{~F}\right)$ & 3 & 6.5 & 4.66 & 3 & 6 & 4.28 \\
\hline 19 & Length of Pelvic-Fin Base $\left(\mathrm{LP}_{2} \mathrm{~B}\right)$ & 0.5 & 2 & 1.44 & 1 & 2 & 1.41 \\
\hline 20 & Length of Anal-Fin (LAF) & 6.5 & 12.5 & 9.19 & 6 & 11 & 8.64 \\
\hline No & Morphometric Characters & \multicolumn{3}{|c|}{ Female (in mm) } & \multicolumn{3}{|c|}{ Male (in mm) } \\
\hline
\end{tabular}




\begin{tabular}{|l|l|c|c|c|c|c|c|}
\hline & & Min & Max & Mean & Min & Max & Mean \\
\hline 21 & Length of Anal-Fin Base (LAB) & 4 & 9 & 7.11 & 4.5 & 8.5 & 6.45 \\
\hline 22 & Length of Caudal-Fin (LCF) & 6.5 & 15 & 9.83 & 6 & 11 & 8.24 \\
\hline
\end{tabular}

The differences of morphometric characters in male and female halfbeak fish were tested using an independent t-test with a 5\% (0.05) confidence interval. The test results show that there are 7 different characters including Total Length (TL), Head Length (HDL), Snout to Pectoral-Fin Distance $\left(\mathrm{SN}-\mathrm{P}_{1} \mathrm{~F}\right)$, Snout to Pelvic-Fin Distance $\left(\mathrm{SN}-\mathrm{P}_{2} \mathrm{~F}\right)$, Pelvic-Fin to Caudal-Fin Distance $\left(\mathrm{P}_{2} \mathrm{~F}-\mathrm{CF}\right)$, Length of Dorsal-Fin (LDF), and Length of Dorsal-Fin Base (LDB).

Based on the results of the analysis of the proportion of morphometric characters to standard length (SL) shown in Table 2, the proportion of morphometric characters that range from $>80 \%$ of the Standard Length (SL) is Total Length (TL). Meanwhile, proportion characters ranged from $30-80 \%$ of the Standard Length (SL) were Snout to Pectoral-Fin Distance $\left(\mathrm{SN}-\mathrm{P}_{1} \mathrm{~F}\right)$; Snout to Pelvic-Fin Distance $\left(\mathrm{SN}-\mathrm{P}_{2} \mathrm{~F}\right)$; and Length of Caudal-Fin (LCF). The proportion of characters that ranged $<30 \%$ were Lower Jaw Length Brembach (LJLB); Head Length (HDL); Body Depth at Pectoral-Fin Base $\left(\mathrm{BDP}_{1} \mathrm{~B}\right)$; Upper Jaw Length (UJL); Lower Jaw Length (LJW); Body Depth at Pelvic-Fin Base $\left(\mathrm{BDP}_{2} \mathrm{~B}\right)$; Depth of Caudal Peduncle (DCP); Pelvic-Fin to Caudal-Fin Distance $\left(\mathrm{P}_{2} \mathrm{~F}-\mathrm{CF}\right)$; Length of Pectoral-Fin $\left(\mathrm{LP}_{1} \mathrm{~F}\right)$; Length of Pectoral-Fin Base $\left(\mathrm{LP}_{1} \mathrm{~B}\right)$; Length of Dorsal-Fin (LDF)); Length of Dorsal-Fin Base (LDB); Length of Pelvic-Fin $\left(\mathrm{LP}_{2} \mathrm{~F}\right)$; Length of Pelvic-Fin Base $\left(\mathrm{LP}_{2} \mathrm{~B}\right)$; Length of Anal-Fin (LAF); and Length of Anal-Fin Base (LAB).

Table 2. The proportion of morphometric characters to standard length (SL)

\begin{tabular}{|c|c|c|c|c|c|}
\hline \multirow{2}{*}{ No } & \multirow{2}{*}{ Morphometric Characters } & \multicolumn{2}{|c|}{ Female } & \multicolumn{2}{|c|}{ Male } \\
\hline & & $\sum(\%)$ & Ratio & $\sum(\%)$ & Ratio \\
\hline 1 & Total Length (TL) & 117.2 & 0.9 & 118 & 0.8 \\
\hline 2 & Lower Jaw Length Brembach (LJLB) & 6.8 & 14.6 & 6.8 & 14.6 \\
\hline 3 & Lower Jaw Length (LJL) & 18.3 & 5.5 & 18.3 & 5.5 \\
\hline 4 & Upper Jaw Length (UJL) & 11.5 & 8.7 & 11.5 & 8.7 \\
\hline 5 & Bony Orbital Diameter (ORBL) & 7.1 & 14.1 & 7.1 & 14.1 \\
\hline 6 & Head Length (HDL) & 28.2 & 3.5 & 29.5 & 3.4 \\
\hline 7 & Snout to Pectoral-Fin Distance (SN-P $\left.\mathrm{P}_{1} \mathrm{~F}\right)$ & 30.4 & 3.3 & 31.6 & 3.2 \\
\hline 8 & Snout to Pelvic-Fin Distance $\left(\mathrm{SN}-\mathrm{P}_{2} \mathrm{~F}\right)$ & 55.6 & 1.7 & 54.7 & 1.8 \\
\hline 9 & Body Depth at Pectoral-Fin Base (BDP $\left.{ }_{1} \mathrm{~B}\right)$ & 16.2 & 6.2 & 16.2 & 6.2 \\
\hline 10 & Body Depth at Pelvic-Fin Base $\left(\mathrm{BDP}_{2} \mathrm{~B}\right)$ & 15.2 & 6.6 & 15.2 & 6.6 \\
\hline 11 & Depth of Caudal Peduncle (DCP) & 7.4 & 13.5 & 7.4 & 13.5 \\
\hline 12 & Pelvic-Fin to Caudal-Fin Distance $\left(\mathrm{P}_{2} \mathrm{~F}-\mathrm{CF}\right)$ & 38.8 & 2.57 & 38.6 & 2.59 \\
\hline 13 & Length of Pectoral-Fin $\left(\mathrm{LP}_{1} \mathrm{~F}\right)$ & 15 & 6.7 & 15 & 6.7 \\
\hline 14 & Length of Pectoral-Fin Base ( $\left.\mathrm{LP}_{1} \mathrm{~B}\right)$ & 2.1 & 46.5 & 2.1 & 46.5 \\
\hline 15 & Length of Dorsal-Fin (LDF) & 15.8 & 6.3 & 16.6 & 6.0 \\
\hline 16 & Length of Dorsal-Fin Base (LDB) & 12.6 & 8.0 & 11.4 & 8.7 \\
\hline 17 & Length of Pelvic-Fin $\left(\mathrm{LP}_{2} \mathrm{~F}\right)$ & 8.2 & 12.3 & 8.2 & 12.3 \\
\hline 18 & Length of Pelvic-Fin Base $\left(\mathrm{LP}_{2} \mathrm{~B}\right)$ & 3.1 & 32.5 & 3.1 & 32.5 \\
\hline 19 & Length of Anal-Fin (LAF) & 18.9 & 5.3 & 18.9 & 5.3 \\
\hline 20 & Length of Anal-Fin Base (LAB) & 14.1 & 7.1 & 14.1 & 7.1 \\
\hline 21 & Length of Caudal-Fin (LCF) & 18 & 5.6 & 18 & 5.6 \\
\hline
\end{tabular}




\subsection{Growth pattern}

The growth pattern analysis revealed that both female and male halfbeak fish were negatively allometric, with female fish having a b-value ranging from 2.795-2.930 and male fish having a b-value ranging from 2.640-2.738.

Female
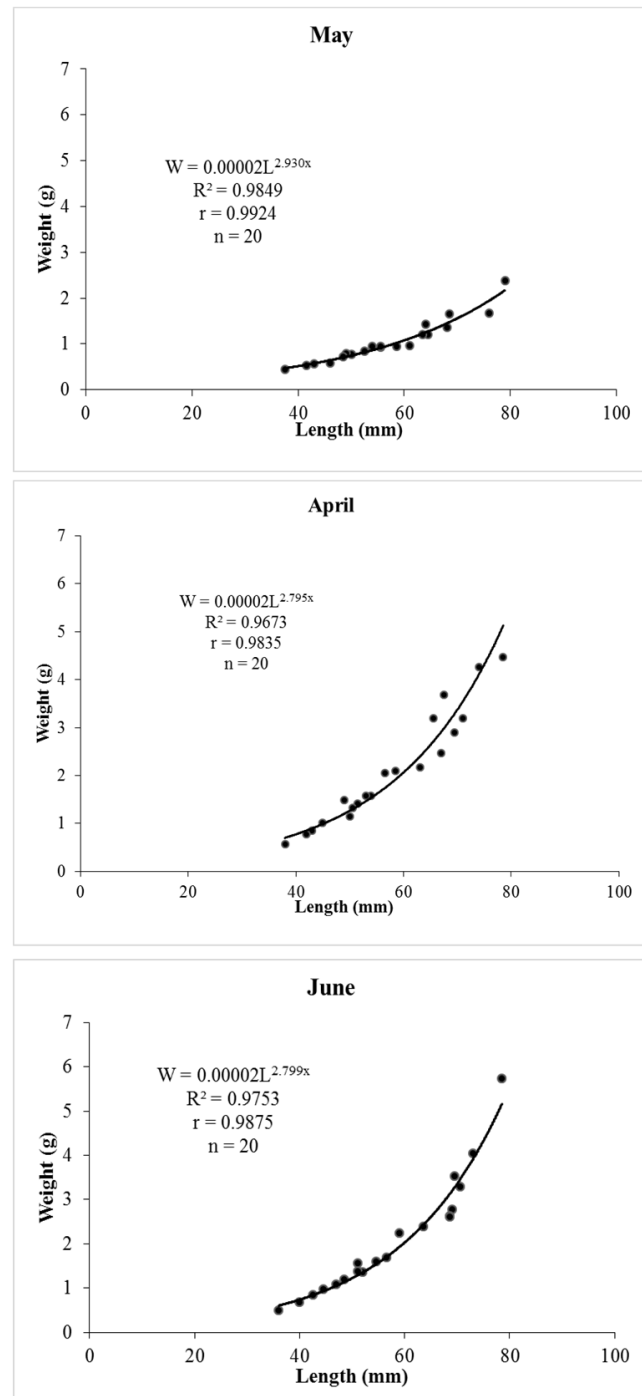

Male

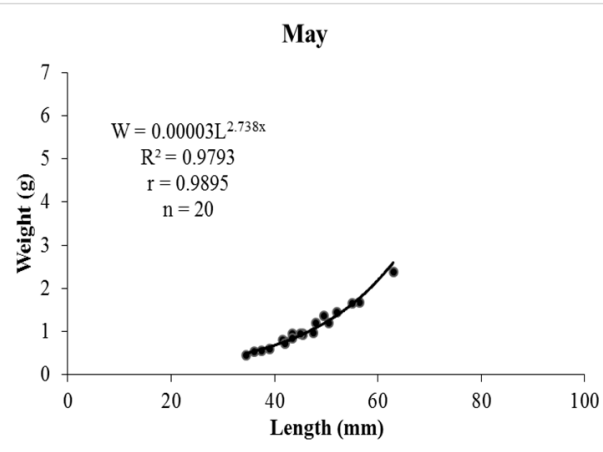

April

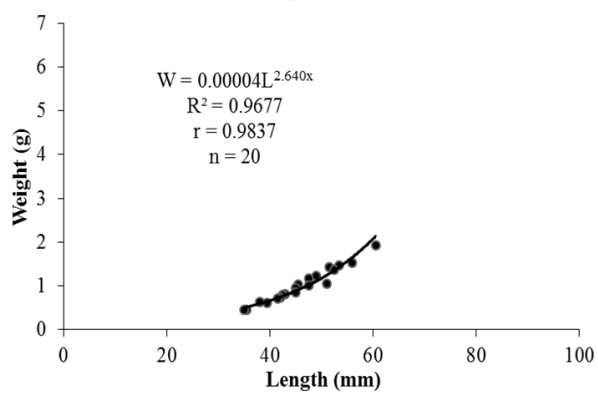

June

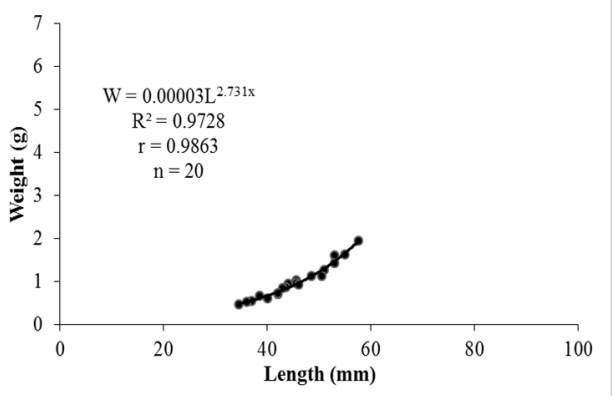

Fig. 3. Growth pattern female halfbeak fish 


\section{Discussions}

\subsection{Morphometric characters}

The morphometric study of halfbeak fish (Nomorhamphus sp.) in Moramo River found that the value of morphometric character in female fish is more significant than male fish.It indicates that female fish have a more substantial body proportion than male fish. This is inconsistent with Meisner's [3] finding that the males in Dermogenys and Nomorhamphus are smaller than the females. [16] also discovered that female Nomorhamphus fish have a larger and longer body than males.

Several studies on morphometric of halfbeak fish in other locations found differences in morphometric value. Nomorhamphus aenigma in Cerekang River, South Sulawesi, Indonesia, has a maximum standard length (SL) recorded $34.7 \mathrm{~mm}$ in males, $60.9 \mathrm{~mm}$ in females [13]. N. rex in Wewu River, South Sulawesi, Indonesia also recorded $44.4 \mathrm{~mm}$ maximum standard length (SL) in males, $63.9 \mathrm{~mm}$ in females [16]. Compared to both $\mathrm{N}$. aenigma and N. rex, Nomorhaphus sp. in Moramo River has a longer maximum SL recorded $63 \mathrm{~mm}$ in males and $79 \mathrm{~mm}$ in females. The difference in the value of this morphometric character is influenced by various factors, including age, gender, and environment. This is in accordance with the statement by [30] that each fish has a different size, depending on age, sex, and environmental conditions. Morphometric variation responds to the physical environment in which the species lives, such as adaptation to specific habitats [15].

Based on the analysis, the proportion of morphometric characters to standard length (SL) found that body deep of Nomorhamphus sp. in Moramo River, BDP ${ }_{1}$ was $15.5-16.2 \%$ $\mathrm{SL}, \mathrm{BDP}_{2}$ was 14.4-15.2 \%. Lower jaw length Brembach (LJLB) shown 14.6-17.1 times ratio in SL. These results are different from other Nomorhamphus species found in Southeast Sulawesi ( $N$. lanceolatus and $N$. sagittarius). $N$. lanceolatus was found in Wawolambo River, between Kolaka and Kendari City with body deep, BDP 1 18.2-20.6 \% $\mathrm{SL}, \mathrm{BDP}_{2}$ 17.9-21.4\% SL. Lower jaw Brembach (LJLB 15-25.3 times in SL). $N$. Sagittarius recorded in Mangolo River, North Kolaka Regency has body deep, $\mathrm{BDP}_{1} 18.2$ $20.6 \%$ SL, $\mathrm{BDP}_{2}$ 17.5-20.7\% SL. Lower jaw elongated (LJLB 6.4-15 times in SL) [17].

\subsection{Growth pattern}

There are variations in the value of $\mathrm{b}$ between males and females Nomorhampus sp. This is caused by variations in the size of males and female fish that are different each time they are caught. The difference in the value of $b$ also be caused by differences in the number and size variations observed [29]. This study discovered that either males or females Nomorhamphus sp. in Moramo River has a negative allometric growth pattern $(b<3)$. It means the length of the fish grows faster than its weight. Another study also reported halfbeak fish on the family of Zenarchopteridae (Zenarchopterus dispar) at Kuala Mamplam, Lhoksumawe City, Indonesia, had a value of $b=2.23$, indicating that the growth pattern of halfbeak fish is negatively allometric.

The morphometric of the observed organisms are also related to the b-value. The morphometric character of the genetic make-up of a fish's body will influence its environmental adaptation and growth pattern. Furthermore, environmental factors such as food availability, temperature, and current conditions influence the difference of b-value. This is in accordance with the statement of Arzita et al. [4] that fish food is a factor that determines the growth and condition of fish. Environmental factors such as currents and 
waves are the main factors that affect the $b$ value of the growth of aquatic animals. In general, aquatic animals that live in calm waters have a considerable $b$ value, while animals living in fast waters tend to have a low $b$ value [34]. Active swimming fish will also show a relatively lower $b$ value than passive swimming fish. This is related to the level of activity of fish movement behavior which is closely related to the habitat where this fish lives.

\section{Acknowledgements}

We want to thank Halu Oleo University's Faculty of Fisheries and Marine Science for providing laboratory facilities for data analysis. Tropical Biosphere Research Center (TBRC), Ryukyu University for kindly provided equipment for data collection. We also thank to Andi Bakri, Muh. Alqaf, Alit Zanuar, La Ode Bazaruddin, La Ode Rifai Sampulawa, and everyone who helped out in the fieldwork.

\section{References}

1. A. De-Robertis, K. William, Trans Am Fish Soc J. 137, 3 (2008)

2. A. D. Meisner, K.D. Louie, Ichthyological Exploration of Freshwaters J. 11, 4 (2000)

3. A. D. Meisner, Zool, Linn. Soc. J. 133 (2001)

4. Arzita, H. Syandri, E. Nugroho, Dahelmi, Syaifullah, Aquaculture J. 7, 3 (2012)

5. Asriyana, Indo. Ichty. J. 15, 1 (2015)

6. Asriyana, N. Irawati, Halili, Biodiversity J. 21, 4 (2020)

7. B. B. Collette, Family Hemiramphidae Gill 1859 - halfbeaks, (California Academy of Sciences, California, 2004)

8. C. M. L. Popta, Zool. Meded. 34 (1912)

9. D. Coates, P.A.M. van Zwieten, Ichthyol. Explor. Freshwat. 3 (1992)

10. D. Vogt, DATZ 31, 1 (1978).

11. G. A. Boulenger, Proceedings of the Zoo-logical Society of London 2 (1897)

12. G. Zhu, L. Xu, Y. Zhou, X. Dai, Acta Ichthyol. Piscat. J. 38, 2 (2008)

13. H. Kobayashi, K.W.A. Masegi, K. Yamahira, Copeia J. 108, 3 (2020)

14. H. M. Gunter, C. Koppermann, A. Meyer, EvoDevo J. 5, 1 (2014)

15. Haryono, Biota J. 6, 3 (2001).

16. J. Huylebrouck, R.K. Hadiaty, F. Herder, Raffl. Bull. Zool. J. 60, 2 (2012)

17. J. Huylebrouck, R.K. Hadiaty, F. Herder, Raffl. Bull. Zool. J. 62, (2014)

18. J. S. Nelson, Fishes of the World. 4th Edition, (John Wiley \& Sons Inc, New York, U 2006)

19. L. R. Parenti, Prosiding Seminar Nasional Ikan VI, 1-10 (2011)

20. M. Brembach, DATZ J. 35, 2 (1982)

21. M. Brembach, Lebendgebärende Halbschnäbler. Untersuchungen zur Verbreitung, Morphologie, Systematik und Fortpfl anzungsbiologie der lebendgebärenden Halbschnäbler der Gattungen Dermogenys und Nomorhamphus (Hemirhamphidae: Pisces (Verlag Natur und Wissenschaft, Solingen, Germany 1991)

22. M. Hashim, D.A.Z. Abidin, S.K. Das, A.G. Mazlan, AACL Bioflux J. 10, 2 (2017) 
23. M. Kottelat, A.J. Whitten, World Bank Publications 343 (1996)

24. M. Kottelat, A.J. Whitten, S.N. Kartikasari, S. Wirjoatmodjo, Freshwater fishes of Western Indonesia and Sulawesi (Periplus Editions Ltd, Hong Kong, 1993)

25. M. Weber, L.F. de Beaufort, Brill Leiden J. 4 (1922)

26. N. Lovejoy, M. Iranpour, B.B. Collette, Integr. Comp. Biol. J. 44 (2004)

27. R. K. Hadiaty, J. Iktiologi Indones. 18, 2 (2018)

28. R. R. Sokal, F.J. Rohlf, W.H. Freeman and Co. 3 (1995)

29. S. S. Kharat, Y. K. Khillare, N. Dahanukar, Ichthyology J. 4, 1 (2008)

30. Turan, Zoo. J. 23 (1998)

31. V. T. Okomoda, I.C.C. Koh, A. Hassan, T. Amornsakun, S.M. Shahreza, AACL Bioflux J. 11, 4 (2018)

32. W. Ladiges, Mitt. Zool. Mus. 68: 207-212 (1972)

33. Z. Zuliani, Z. A. Muchlisin, N. Nurfadillah, Marine and Fish. Stu. Sci. Unsyiah J. 1, 1 (2016)

34. Z. A. Muchlisin, M. Musman, M.N. Siti Azizah, Applied Ichthyology J. 26 (2010) 